\title{
SPECIFICATIONS OF CREATING THE COMBINED FROZEN HALF-PRODUCTS OF FRUIT AND BERRIES
}

\author{
G. Simakhina
}

National University of Food Technologies

\begin{tabular}{l}
$\quad$ Key words: \\
Fruit \\
Berries \\
Composition \\
Radioprotectory action \\
Bioflavonoids \\
Algorithm \\
\hline
\end{tabular}

Article history:

Received 07.09.2018

Received in revised form

26.09.2018

Accepted 08.10.2018

Corresponding author:

G. Simakhina

E-mail:

npnuht@ukr.net

\begin{abstract}
Nutrition in extreme conditions of life attains the special importance. It needs the increased concentrations of all the necessary nutrients, including first of all vitamins and some other biologically active substances. Fruit and berries are the main source of these substances; moreover, wild raw materials usually exceed the cultural sorts by content of the majority of biocomponents. Preservation of this kind of raw with usage of low temperatures would allow obtaining the half products with gained biological value, which are irreplaceable in nutrition of special contingents.

The results of our theoretical and experimental researches showed the effectiveness of combining in a certain frozen half product various fruit and berry cultures, compatible with their technological indices and natural set of biocomponents, from the viewpoint of their synergism. Therefore, it is possible to elaborate the half products with different functional destination (adaptogenous, immunomodulating, radioprotective, disintoxication etc.). For example, we proved scientifically the combination of guelder, aronia, and blackberries within the framework of our research. We also formulated the algorithm of prognostication, obtaining and usage of the half products, and gave comments to each of its component.

The main conclusion of this work is that the well-grounded approach to the fruit and berry composition on all stages of its elaboration is the warranty of its forecast functionality, absolute safety, and wide demand in consumers. The novelty of this research is the preference to use not the separate biological objects, but their compositions whose components are able to potentiate each other's effect both in obtained products and in alimentary canal in order to impact the life processes positively.
\end{abstract}

DOI: $10.24263 / 2225-2924-2018-24-5-18$ 


\title{
ОСОБЛИВОСТІ СТВОРЕННЯ КОМБІНОВАНИХ ЗАМОРОЖЕНИХ ПЛОДОВО-ЯГІДНИХ НАПІВФАБРИКАТІВ
}

\author{
Г.О. Сімахіна \\ Національний університет харчових технологій
}

В екстремальних умовах життєдіяльності харчування набуває особливого значення. Воно потребує підвищених концентрачій необхідних для організму нутрієнтів, передусім вітамінів та інших біологічно активних речовин. Основним їх джерелом є культивовані й дикорослі плоди та ягоди, причому дикоросла сировина, зазвичай, переважає культурні сорти за вмістом більшості біокомпонентів. Консервування цієї сировини з використанням низьких температур дає можливість отримати напівфабрикати підвищеної біологічної иінності, незамінні у раиіонах харчування спеиякотингентів.

Результати виконаних нами теоретичних та експериментальних досліджень показали ефективність поєднання у складі заморожених напівфабрикатів різних плодово-ягідних культур, сумісних за своїми технологічними показниками, природним набором біокомпонентів із точки зору синергізму їхньої діі. Таким чином можна створити напівфабрикати різного функиіонального спрямування - адаптогенного, імуномодулюючого, радіопротекторного, дезінтоксикаційного тощо. Наприклад, у межах виконання иьього дослідження науково обтрунтовано створення композицій із плодів калини та аронії чорноплідної $і$ ягід ожини. Сформульовано також алгоритм прогнозування, отримання та використання напівфабрикатів, дано коментарі до кожної його складової.

Висновком за результатами виконаного дослідження є те, що трунтовний підхід до створення композииійної плодово-ягідної сумімі - гарантія ії прогнозованої функціональності, абсолютної безпеки $i$ широкого попиту у споживачів. Новим у иих дослідженнях є надання переваги використанню не окремих біооб'єктів, а їхніх композииій, складові яких здатні потениіювати дію одна одної як у складі отриманих продуктів, так $і$ на рівні шлунковокишкового тракту, справляючи різнобічні позитивні ефекти.

Ключові слова: плоди, ягоди, композиція, радіопротекторна дія, біофлавоноїди, алгоритм.

Постановка проблеми. Істотне місце у системі заходів зі збереження, підтримання та розвитку потенціалу популяційного та індивідуального здоров'я населення України, поряд зі способом життя, традиціями, соціальноекономічним становищем, посідає харчовий статус. Якщо харчовий раціон збалансований та адекватний нутрієнтним потребам людини, відповідає вимогам медичної науки і водночас враховує національні традиції та звички, то він сприятиме і забезпечуватиме як підтримання, так і збільшення потенціалу здоров’я. Такий харчовий раціон сьогодні має статус здорового харчування. 
Саме за рахунок здорового харчування можна значно поліпшити роботу різних органів та систем організму людини, підвищити його стійкість до впливу іонізуючого випромінювання, дії токсичних речовин та інших негативних чинників довкілля, в тому числі психоемоційних, що $\epsilon$ особливо важливим для життєдіяльності спецконтингентів - військовослужбовців, рятувальників, спортсменів тощо [1].

У структурі здорового харчування вирішальну роль відіграє плодовоягідна сировина як джерело вітамінів та інших біологічно активних речовин [2]. Тому питання збільшення виробництва харчових продуктів на основі цієї сировини, поліпшення їхньої якості, харчової цінності та смакових характеристик $\epsilon$ надзвичайно актуальним. Світовий досвід переконливо свідчить про те, що єдиним способом перероблення плодово-ягідної сировини, який забезпечує практично повне збереження усіх цінних біокомпонентів, $є$ використання низькотемпературних впливів [3].

Необмежене поле діяльності у вирішенні проблеми збільшення випуску напівфабрикатів науковці знаходять серед дикорослої плодово-ягідної сировини. Вона поки що є нетрадиційною для виробництва продуктів оздоровчого, профілактичного, лікувального призначення. Однак спектр її застосування у харчовій промисловості поступово розширюється, особливо у виробництві безалкогольних, слабоалкогольних, соковмісних напоїв, заморожених напівфабрикатів тощо.

Аналіз останніх досліджень і публікацій. Практично все населення України перебуває під постійним впливом малих і надмалих доз радіоактивного опромінення, яке викликає набагато серйозніші наслідки, ніж високі дози короткочасного опромінення. І на основі того, що відомо на сьогодні, можна говорити про високу активність малих і надмалих доз. Так, у [4] показано, що надмалі дози опромінення викликають розриви в молекулах ДНК, впливаючи на геном людини. У зв'язку з цим варто виділити один із чинників, що впливає на стан здоров'я людини і популяції та здатний захистити організм від ендо- та екзогенних забруднювачів, - чинник харчування.

Усе, окрім кисню, людина для своєї життєдіяльності отримує з їжі та води. Їжа в процесі споживання перетворюється із зовнішнього на внутрішній чинник, і ії компоненти в ланцюжку послідовних перетворень трансформуються в енергію фізіологічних функцій та структурні елементи органів і тканин організму людини [5]. В сучасних умовах очевидним $є$ два відносно самостійні аспекти взаємозв'язку харчування і процесів біотрансформації компонентів їжі та чужорідних сполук (контамінантів) в організмі людини. Один із цих аспектів полягає в тому, що їжа $є$ не лише носієм пластичних та енергетичних матеріалів, а й джерелом компонентів неаліментарного (нехарчового) характеру, серед яких немало сполук природного або антропогенного походження [6]. Водночас хімічний склад їжі як у традиційному їі розумінні (вміст харчових та біологічно активних речовин), так і з урахуванням неаліментарних компонентів, справляє регульований вплив на всі системи живого організму, що відповідають за транспорт, метаболізм, знезараження та елімінацію ксенобіотиків. Ось чому проблема їх виведення з організму - одна з найважливіших для населення України. Тому у сфері інноваційних технологій необхід- 
ним $є$ розвиток грунтовних досліджень 3 пошуку нових природних джерел для отримання широкого спектра функціональних інгредієнтів і продуктів радіопротекторної дії для безпосереднього використання, а також для збагачення традиційних харчових середовищ.

Літературні дані, наведені різними авторами, свідчать про багатий біокомпонентний склад дикорослих плодів і ягід. Так, плоди аронії чорноплідної, глоду багаті на каротиноїди, антоціани, вітаміни, мінеральні елементи, вітамін РР. Останній бере участь у реакціях клітинного обміну, в білковому обміні і підвищує ступінь використання в організмі рослинних білків, нормалізує секреторну функцію шлунка тощо [7]. За даними [8], плоди аронії містять близько 45 мг\% вітаміну С, 7\% фенольних сполук, у тому числі близько $2 \%$ флавоноїдів. Наші дослідження [9] підтвердили результати інших авторів щодо доцільності використання дикорослих плодів і ягід як джерела аскорбінової кислоти (аронія чорноплідна — $120 \ldots 130$ мг\%, ожина — 60... 70 мг\%, калина — 35...40 мг\%); біофлавоноїдів (відповідно 2466 мг\%, 2447 мг\%, 1345 мг\%).

Наведені дані стосовно рослинних об'єктів як джерел вітамінів та інших БАР необхідно пов'язувати 3 їхнім впливом на функціонування організму. Тому повністю погоджуємось із твердженням Айзека Азимова: «Першим серйозним досягненням медицини стало визнання лікарями факту, що однією iз запорук здоров'я є проста і збалансована дієта» [10].

I у вирішенні цієї проблеми важливу роль відіграє плодово-ягідна сировина, єдиним недоліком якої є сезонність їі вирощування та необхідність пошуку найефективніших методів консервування. Учені, які працюють у цьому напрямі, єдині в одному: таким методом є заморожування сировини [3; 11$]$. Для створення оптимальних за складом композиційних сумішей, призначених для заморожування, з урахуванням направленості дії окремих біокомпонентів та дотримання їх необхідних співвідношень, доцільно скористатись загальними принципами харчової комбінаторики [12]: безпека та доброякісність, достатність та пріоритет використання, сумісність, кінцевий контроль. Про досконалість цих принципів та їх практичну реалізацію свідчать дослідження вітчизняних учених [13; 14], і тому подальше їх впровадження сприятиме підвищенню якості розроблених продуктів, їхньої безпеки та ефективності.

Мета дослідження: науково обгрунтувати вибір плодово-ягідних культур за їхніми технологічними характеристиками та синергізмом дії основних біокомпонентів і створити композиції заморожених напівфабрикатів для осіб, що перебувають в екстремальних умовах життєдіяльності.

Викладення основних результатів дослідження. За аналогією 3 фітопрепаратами, заморожені напівфабрикати віднесемо до простих, якщо до їхнього складу входять плоди чи ягоди одного сорту (виду), та складних, що являють собою суміш декількох видів плодів і ягід. Розглянемо послідовність дій при створенні складних плодово-ягідних напівфабрикатів радіопротекторної дії. Обрана сировина обов'язково повинна містити в достатніх концентраціях компоненти, які запобігають накопиченню радіонуклідів та прискорюють їх виведення 3 організму, захищаючи його від невеликих доз постійного i, як уже зазначали, надзвичайно шкідливого радіоактивного опромінення. 
Інтерес до дикорослих плодово-ягідних рослин, що поновився в останні роки, спонукає дослідників звертати увагу на спектр такої сировини переважно вітчизняної флори. Наукові дослідження в галузі хіміко-фармацевтичних наук, нутриціології, фармаконутриціології, харчової хімії, використання ресурсоощадних, високоефективних технологій і наявність обладнання дає можливість створювати все досконаліші науково обгрунтовані композиції 3 доведеним позитивним впливом на певні органи та функції організму людини, в цьому разі таким, який здатен захищати клітини живого організму від радіоактивних уражень та інших несприятливих чинників довкілля.

Науково обгрунтований вибір плодів та ягід для майбутньої композиційної суміші заморожених напівфабрикатів повинен ураховувати й відмінності в структурі покривних тканин об'єктів дослідження, які апріорі можуть впливати на особливості заморожування матеріалів. У ботаніці залежно від компонентів, які формують склад захисних покривних тканин рослини, запропоновано таку класифікацію [15]: рослини з ніжною покривною тканиною i міжклітинниками (1-а група) й товстостінні зі щільною покривною тканиною без міжклітинників (2-а група). Відповідно до цієї класифікації, ми віднесли до 1-ї групи культивовані та дикорослі плоди і ягоди малини, суниці, смородини чорної, порічки червоної, чорниці тощо, а до 2-ї (зі щільною покривною тканиною) - плоди калини та аронії чорноплідної, ягоди ожини, журавлини, терену, агрусу.

Оскільки, за результатами виконаних нами досліджень, структура покривних тканин істотно впливає на здатність біооб'єктів до холодових адаптацій [16; 17], то склад сумішей доцільно формувати із плодів та ягід, що належать до 1-ї або 2-ї груп. Тому подальші дослідження проводили на плодах калини та аронії чорноплідної і ягодах ожини.

При формуванні комплексу плодів та ягід для заморожених напівфабрикатів ураховували також, що надходження енергії в організм людини регулюється складною системою, фізіологічними проявами якої є апетит й органолептичні характеристики продуктів, передусім смак і колір. Відомо, що смакові властивості плодово-ягідної сировини визначаються оптимальним співвідношенням вмісту цукрів та органічних кислот - глюкоацидометричним індексом. За даними [9], для аронії чорноплідної він становить 7,96; для ожини $-7,05$; для калини - 5,5. Загалом цей показник для скомпонованої суміші, в якій усі складники взято у рівних співвідношеннях, становить 6,84 , що входить до діапазону його оптимальних значень. Кольору обраним видам плодів та ягід надають антоціани.

При створенні композицій необхідно обирати ті сировинні матеріали, біохімічний склад і фармакологічна активність яких не викликають сумнівів, а також проводити експерименти із 3'ясування концентрації тих біокомпонентів, які виявляють виражений радіопротекторний ефект: біофлавоноїдів, аскорбінової кислоти, каротиноїдів, пектинових речовин, органічних кислот, кальцію. Тому дослідженню саме цих нутрієнтів і приділено основну увагу. За стандартними методиками визначили їхній вміст у сировині. Результати зведено до таблиці. 
Таблиия. Вміст основних біокомпонентів у плодово-ягідній сировині, $P \geq 0,95 ; n=3$

\begin{tabular}{|c|c|c|c|c|c|}
\hline Дослідні зразки & $\begin{array}{c}\text { Біофлавоноїди, } \\
\text { мг\% }\end{array}$ & $\begin{array}{c}\text { Вітамін С, } \\
\text { мг\% }\end{array}$ & $\begin{array}{c}\text { Каротиноїди, } \\
\text { мг\% }\end{array}$ & $\begin{array}{c}\text { Органічні } \\
\text { кислоти, в } \\
\text { перерахунку } \\
\text { на яблучну, \% }\end{array}$ & $\begin{array}{c}\text { Пектинові } \\
\text { речовини, \% }\end{array}$ \\
\hline Плоди калини & 1626,0 & 29,25 & 1,4 & 0,96 & 2,2 \\
\hline $\begin{array}{c}\text { Плоди аронії } \\
\text { чорноплідної }\end{array}$ & 1912,0 & 97,7 & 3,2 & 1,34 & 1,65 \\
\hline Ягоди ожини & 2120,0 & 76,1 & 2,6 & 1,25 & 2,8 \\
\hline
\end{tabular}

Зважаючи на те, що ягоди ожини містять максимальну кількість біофлавоноїдів і пектинових речовин, значні концентрації вітаміну $\mathrm{C}$ та органічних кислот, обрано такий склад плодово-ягідної суміші для отримання заморожених напівфабрикатів: ягоди ожини - 40\%; плоди калини - $30 \%$; плоди аронії чорноплідної - $30 \%$.

Враховуючи високий вміст у цих рослинах біофлавоноїдів, аскорбінової кислоти, каротиноїдів, пектинових речовин, які діють синергічно, прогнозуємо їхній істотний антитоксичний ефект на організм людини [18], постачання його необхідними біокомпонентами. Пектинові речовини та органічні кислоти захищають клітини при заморожуванні, зберігаючи їхню цілісність та якість отриманих композицій.

Відповідно до даних таблиці, сировина містить значні концентрації біофлавоноїдів (від 1626 до 2120 мг\%), вітаміну С, особливо в ягодах ожини та плодах аронії чорноплідної. Вміст каротиноїдів незначний (від 1,4 до 3,2 мг\%), однак завдяки великій кількості подвійних зв'язків вони беруть активну участь в окислювально-відновних процесах [19].

У подальших дослідженнях сформульовано алгоритм прогнозування, отримання та використання напівфабрикатів, дано коментарі до кожної його складової.

Блок 1. Постановка мети розроблення напівфабрикату. Відповідно до блоку 1 , поставлено за мету отримати заморожений напівфабрикат із плодово-ягідних культур для цілорічного постачання населення України високовітамінною продукцією, компоненти якої мають радіопротекторні властивості і включатимуться до системи захисту живого організму від невеликих доз постійного опромінення.

Блок 2. Аналіз напівфабрикату за сукупністю параметрів, що визначають його ефективність. Передбачає підбір багатокомпонентних рослинних матеріалів. Їхні складові повинні взаємно доповнювати одна одну, потенціюючи дію біологічно активних речовин (вітамінів, поліфенольних сполук, каротиноїдів, мінеральних елементів, органічних кислот, пектинових речовин тощо).

Блок 3. Встановлення переваг біологічної активності та поліфункиіональності напівфабрикату. У межах реалізації блоку 3 даного алгоритму встановлюємо переваги майбутньої композиції на підставі аналізу біохімічного складу її компонентів, їхньої біологічної активності та поліфункціональності. 
Блок 4. Виявлення можливих недоліків напівфабрикату. 3 блоку 4 зрозуміла необхідність медико-біологічної оцінки обраних плодово-ягідних матеріалів 3 точки зору виявлення можливих недоліків готового продукту (наявності сильнодіючих сполук, підвищеної концентрації певної біологічно активної речовини), що обмежує використання таких напівфабрикатів для певної категорії споживачів.

Блок 5. Прогнозування варіантів удосконалення напівфабрикату. Цей блок має окреслити шляхи усунення виявлених недоліків, наприклад за рахунок введення до композиції інших рослин, позбавлених установлених вад.

Блок 6. Уточнення оптимального варіанта напівфабрикату. За блоком 6 дається вже уточнений варіант плодово-ягідної композиції.

Блок 7. Врахування $і$ запобігання можливим небажаним ефектам. За блоком 7 мають бути передбачені такі технологічні процеси, застосування яких забезпечує отримання високоякісних заморожених напівфабрикатів із належними органолептичними характеристиками, наприклад шокове заморожування, попереднє оброблення плодів та ягід кріопротекторами тощо.

Блок 8. Перелік вимог до найбільш ефективного функиіонування напівфабрикату. За блоком 8 розробляється документація, за якої виробництво та використання нового напівфабрикату буде найбільш ефективним (технічні умови, технологічна інструкція, рекомендації з використання готової продукції тощо).

Блок 9. Техніко-економічна, соиіально-екологічна, психологічна оцінка напівфабрикату. Психологічна оцінка композиції полягає в тому, як сприймає споживач нову продукцію, оскільки вона може не відповідати його традиційним смакам та уподобанням, а також передбачає проведення роз'яснювальної роботи з корисності даної продукції для здоров'я.

Блок 10. Технологія нового напівфабрикату.

Блок 11. Патентування способу отримання напівфабрикату.

Блок 12. Реклама та промислово-комериійна реалізація нового напівфабрикату.

Блок 13. Масштаби задоволення потреби населення у новому напівфабрикаті.

Блок 14. Оиінка конкурентоспроможності та експортоорієнтованості нового продукту.

Блоки 10-14 є практичною реалізацією наведених теоретичних передумов і виконуються безпосередньо на підприємствах з виробництва заморожених напівфабрикатів. Виконання блоку 14 передбачено вимогами до інноваційної продукції з точки зору оцінки іiї конкурентоспроможності та реалізації на внутрішньому і зовнішньому ринках.

Запропоновані нами підходи до отримання заморожених напівфабрикатів узгоджуються 3 першим принципом харчової комбінаторики - принципом безпеки та доброякісності. Згідно з ним, при розробленні нових видів харчової продукції необхідно використовувати сировину, матеріали та різноманітні добавки, рекомендовані та дозволені для використання в харчовій промисловості (блок 2). Другий принцип харчової комбінаторики — принцип необхід- 
ності (достатності) використання. Кодекс Аліментаріс трактує його так: коли бажаного ефекту можна досягти шляхом технологічного оброблення природної сировини або напівфабрикатів, то використовувати хімічні добавки недоцільно. Відповідно до наведеного алгоритму, йдеться винятково про натуральну сировину. Третій принцип харчової комбінаторики - принцип сумісності. При підборі композиції плодів та ягід ми враховували технологічну та фізико-хімічну сумісність їхніх інгредієнтів. Четвертий принцип принцип переваги використання і рівнозначності контролю. Сутність цього принципу полягає в тому, що при створенні продукції оздоровчого призначення перевагу необхідно надавати природним сировинним матеріалам. П'ятий принцип харчової комбінаторики - принцип кінцевого контролю і ймовірності декларування. Реалізація цього принципу визначає необхідність перевірки показників безпеки не лише сировини, а й продуктів на іï основі. Останній принцип - принцип виключення, суть якого полягає в необхідності змінити рецептуру композиції в разі отримання негативних результатів $\mathrm{i}$ можливих побічних ефектів. Саме цим питанням присвячено реалізацію блоків 4-7 у запропонованому алгоритмі.

\section{Висновки}

Грунтовний підхід до створення композиційної плодово-ягідної суміші $€$ гарантією іï прогнозованої функціональності, абсолютної безпеки і широкого попиту у споживачів. Новим у цих дослідженнях $\epsilon$ те, що перевага надається використанню не окремих біооб'єктів, а їхніх композицій, складові яких здатні потенціювати дію одна одної як у складі отриманих продуктів, так і на рівні шлунково-кишкового тракту, справляючи різнобічні ефекти, у тому числі антитоксичні. Розроблені композиції напівфабрикатів рекомендуються до вживання для запобігання негативним впливам малих доз постійного радіоактивного опромінення, важких металів, інших негативних чинників як у побуті, так і на виробництві, особливо в екологічно несприятливих районах; як допоміжний засіб у реабілітації хворих, що пройшли курс променевої терапії, особам після важких захворювань для підтримання імунного статусу, а також для спецконтингентів.

\section{Література}

1. Капрельянц Л.В., Петросьянц А.П. Лікувально-профілактичні властивості харчових продуктів та основи дієтології: монографія. Одеса: Друк, 2011. 260 с.

2. Хомич Г.П. Плоди дикорослої сировини - джерело біологічно активних речовин для харчових продуктів. Наукові пращуі ОНАХТ. 2009. Т. 2. Вип. 36. С. 186-190.

3. Сімахіна Г.О., Науменко Н.В. Низькі температури у технологіях оздоровчих продуктів: монографія. Київ: Сталь, 2011.363 с.

4. Тушманова Н.А. О биологическом значении сверхмалых доз. Международный медииинский журнал. 1999. № 9-10. С. 547-548.

5. Яковенко А.Ф., Яковенко Б.В. Биохимия: Учеб. пособие. Сумы: Изд-во «Университетская книга», 2001. 374 с.

6. Позняковский В.М. Гигиенические основы питания, безопасность и экспертиза продовольственных товаров: учебник. Новосибирск: Изд-во Новосиб. ун-та, 1999. 448 с.

7. Ильина С.И. Двенадцать месяцев здоровья. Киев: Логос, 2000. 320 с. 
8. Семенів Д. Дослідження властивостей субстанцій аронії чорноплідної. Проблеми екологічної та медичної генетики і клінічної імунології. 2014. Вип. 1. С. 160-165.

9. Сімахіна Г.О. Основні показники придатності плодів та ягід до заморожування. Вчені записки Таврійського національного університету імені В.І. Вернадського. 2018. T. 29, № 1. С. $73-77$.

10.Азимов А. Путеводитель по науке. От египетских пирамид до космических станций. Москва: ЗАО Центрполиграф, 2005. 788 с.

11. Орлова Н.Я., Белінська С.О. Заморожені плодоовочеві продукти: проблеми формування ассортименту та якості: монографія. Київ: КНТЕУ, 2005. 335 с.

12. Рыбников К.А. Введение в комбинаторный анализ. Москва: МГУ, 1985. 308 с.

13. Белінська С.О. Наукові і практичні засади розроблення рецептур і формування якості швидкозаморожених плодоовочевих продуктів. Харчова $i$ переробна промисловicmь. 2009. № 11-12. С. 26-28.

14. Притульська Н.В., Гуліч М.П., Мотузка Ю.М. та ін. Ентеральна нутритивна підтримка населення в умовах надзвичайних ситуацій: монографія. Київ: КНТЕУ, 2018. 280 с.

15. Сербін А.Г., Сіра Л.М., Слободянюк Т.О. Фармацевтична ботаніка: підручник. Вінниця: Нова книга, 2007. 488 с.

16. Сімахіна Г.О., Халапсіна С.В. Особливості заморожування ягід із ніжною текстурою. Наукові пращуі національного університету харчових технологій. 2015. № 4. C. $198-206$.

17. Сімахіна Г.О., Халапсіна С.В. Отримання заморожених напівфабрикатів дикорослих ягід зі щільною покривною тканиною. Наукові праці національного університету харчових технологій. 2016. № 3. С. 198-206.

18. Спиричев В.Б., Шатнюк Л.Н., Позняковский В.М. Обогащение пищевых продуктов витаминами и минеральными веществами. Наука и технология. Новосибирск: Сиб. унив. изд-во, 2005. 548 с.

19. Петрова В.П. Биохимия дикорастущих плодово-ягодных растений. Киев: Вища школа, 1986. 287 с. 